\title{
Have Centuries of Inefficient Fishing Sustained a Wild Oyster Fishery: a Case Study
}

\author{
Stephen Long ${ }^{1,2,3^{*}}$, Richard Ffrench-Constant ${ }^{1}$, Kristian Metcalfe ${ }^{2}$ and Matthew J Witt ${ }^{1}$ \\ ${ }^{1}$ Centre for Ecology and Conservation, University of Exeter, Penryn Campus, Cornwall, TR10 9FE, UK \\ ${ }^{2}$ Environment and Sustainability Institute, University of Exeter, Penryn Campus, Cornwall, TR10 9FE, UK \\ ${ }^{3}$ Department of Geography, University College London, Pearson Building, Gower Street, London, WC1E 6BT, UK
}

"Corresponding author: Stephen Long, Department of Geography, University College London, Pearson Building, Gower Street, London, WC1E 6BT, UK, Tel: +44 20 7679 2000; E-mail: stephen.long.16@ucl.ac.uk

Received date: March 31, 2017; Accepted date: April 21, 2017; Published date: April 28, 2017

Copyright: ( 2017 Long S, et al. This is an open-access article distributed under the terms of the Creative Commons Attribution License, which permits unrestricted use, distribution, and reproduction in any medium, provided the original author and source are credited.

\begin{abstract}
The native European flat oyster (Ostrea edulis) has declined throughout its range, due to over-exploitation, a situation mirrored in oyster stocks globally. There are three remaining oyster fisheries in England (Fal, Solent, and Thames Estuary). The Fal oyster fishery though employs traditional methods, using hand-hauled dredges from rowing punts or under sail and is home to the last commercial sailing fleet in Europe. Against a backdrop of temporary closures to protect dwindling stocks in the Solent and Thames Estuary, this study considers whether the longevity of the Fal oyster fishery is linked to the traditional methods that have been employed for centuries. Using GPS tracking in combination with on board observers, we demonstrate that dredging under sail is inefficient compared to more modern mechanically powered methods that are utilised elsewhere. A review of historical landings suggests that both overall landings and fishing effort have declined. The fishery appears to have gone through cycles of over-exploitation and one closure due to disease. However, the key to the long-term survival of the Fal oyster fishery may be linked to the traditional method of dredging. It is estimated that a switch from traditional methods to modern techniques would result in a greater than 9 fold increase in effort per season. The data presented highlight this unique fishery as a counterfactual to the increases in power seen in commercial fisheries over the last century and serve as a reference point for future studies.
\end{abstract}

Keywords: Oysters; Shellfish; Artisanal; Small scale fisheries; Traditional; Fishery

\section{Introduction}

Despite recognition that centuries of marine exploitation have drastically reduced stocks of formerly abundant marine species [1], unsustainable fishing continues on a global scale [2]. There is now significant scientific and economic interest in rebuilding collapsed fisheries and ensuring marine resources are used sustainably [3,4]. Achieving such sustainability will be particularly challenging given the wide range of fishing practices, their target stocks and host ecosystems. The sedentary adult phase of bivalves, such as scallops, oysters and mussels, make local populations highly vulnerable to over exploitation leading to the collapse of fisheries [5].

Oysters are environmentally and economically important; they act as ecosystem engineers producing biogenic reef habitat [6], as well as providing ecosystem services including water filtration, food provision, habitat and coastal defence [7]. Oysters are of significant economic value particularly to coastal communities, with global production from aggregated country level data of 5.3 million tonnes in 2014, of which the vast majority (5.1 million tonnes) was from aquaculture $[8,9]$. However, long term exploitation has edged oyster reefs to extinction, with an estimated $85 \%$ of oyster reefs lost globally [10].

The native or European flat oyster (Ostrea edulis, L.) is a sessile, filter feeding, bivalve mollusc, once highly abundant, ranging throughout the Mediterranean and Atlantic coasts of Europe [11]. The species and the oyster beds they form are on the OSPAR List of
Threatened and/or Declining Species and Habitats [12], and are typically included as biodiversity action plan species where they occur (e.g. UK BAP). Historically, over-exploitation and other factors have led to declines since the early 18 th century, with wild populations reportedly scarce around Europe by the 1940s [13,14]. Landings of native oysters have significantly declined in the United Kingdom and across Europe $[11,13,15]$. In England and Wales landings have fallen by $98 \%$, from more than 2000 tonnes in the 1920s [16] to 39 tonnes in 2015 [17]. In England and Wales only three oyster fisheries remain, these are found in the Solent, Thames Estuary and River Fal [16].

The Fal oyster fishery has been in operation since the Roman times [18], and still employs traditional fishing methods. Hand-hauled dredges are operated from two forms of non-mechanically powered boat. These are sailing boats and haul tow punts, the latter being where boats are hand winched to a previously deployed anchor whilst towing dredges. These practices are dictated by the management authority, and so the fishery is considered home to the last commercial sailing fleet in Europe [18]. The fishery lies within the Fal and Helford Special Area of Conservation (SAC), as per the EC Habitats Directive [19], where all forms of bottom dredging are now banned with the exception of traditional oyster dredging methods which continue under a special dispensation. Historically the fishery was principally a brood stock fishery, providing stock for on-growing to areas including the Helford estuary in Cornwall and Essex oyster beds [20,21]. However, the oyster disease Bonamia-caused by the parasite Bonamia ostreae has had a significant impact on local stocks. Introduced to Europe via spat from the USA in the late 1970s it was first identified in the UK in the Fal and Helford estuaries in 1982 [20] and rendered fishing unprofitable 
during the 1980's [22,23]. At the time the spread of the disease was managed though the use of movement controls [24], which would have prevented operation as a brood stock fishery. Stock levels remained low throughout the 1980's, with increasing catches through the 1990's [24,25], presumably associated with increased fishing effort. Despite the unique nature of the fishery and the ecological complexity of the Fal estuary it has attracted relatively little scientific investigation. The Fal Oyster currently has Protected Designation of Origin status [23] and is sold to both the food industry and into aquaculture as brood stock. Annual landings of approximately 50-60 tonnes [18], makes an economic contribution to an economically deprived region of the UK.

The fishery offers a sharp contrast to the industrialisation and increased fishing power of almost all other fisheries throughout the North Atlantic Ocean over the last two centuries, which has been linked to stock declines and fishery collapse [26,27]. Set against this historic back-drop the current study aims to highlight the Fal as a fishery that has maintained traditional practices and not exhibited the increases in fishing power through technological advances. More specifically the comparative inefficiency of these traditional practices is considered. Historic and new data are combined to offer insights into the long-term trends, current operation of the fishery and to provide a reference point. Whilst establishing strict causality is not possible in a data-deficient context the comparatively inefficient dredging methods may have preserved viable stocks accounting for the longevity of this traditional fishery.

\section{Methodology}

\section{Description of the Fal fishery}

The total area of the fishery is estimated as 1,101 hectares [28] this being the total dredgable area below the mean low water mark between the southerly limit (a line between St. Mawes Castle and Trefusis Point) and the northerly limit (Malpas) of the fishery (Figure 1a). For the purposes of annual surveys the UK Centre for Environment Fisheries and Aquatic Sciences (Cefas) divided the fishery into three sections, the River, Harbour and Outer Harbour Sections (Figure 1a) which are also referred to in this study $[25,29]$.

\section{Regulation and operation of the current fishery}

The Truro Port Fishery Order 1936 (amended 1975 and 1984) regulated the fishery until expiry of the order on 31st July 2014 [28,30-32]. Due to delays in the development of a new regulating order, an emergency byelaw was enacted from 13th March 2015 for a maximum of 12 months [32,33]. The emergency byelaw, was replaced by The Fal Fishery Order 2016 [34]. The emergency byelaw and subsequent 2016 order adopted the principal management measures from the original expired order, specifically: i) that fishing must not use mechanical power (neither to propel vessels or haul dredges), ii) a Minimum Landing Size (MLS) of 2 5/8' (67 mm), iii) a season (1st October to 31st March; 182 days), iv) fishery hours (dredging between 09:00 to 15:00 Monday to Friday, 09:00 to 13:00 on Saturdays) and v) fishermen must purchase a licence ( $£ 165.00$ in the $2016 / 17$ season) for each dredge they operate [33]. Sail boats operate in the Harbour, and to a lesser extent Outer Harbour (Figure 1a). In practice, only the northern most portion of the Outer Harbour Section is dredged, with no activity on Falmouth Bank and St. Mawes Bank, as the substrate here is unsuitable for oyster settlement [25]. Sail boats drift down wind and tide whilst towing dredge gear, before sailing back up to repeat the process. Sail boats are crewed by 1 or 2 men, operating 2 or 4 dredges respectively. Dredges are hauled and contents sorted alternately through the course of each drift. Haul-tow boats are small punts and operate in the River section. The dredge is towed as the fishermen winches, by hand, back to an anchor deployed a short distance away. Upon hauling, the contents of the dredge, known as cultch (term also applies to spat settlement substrate), is sorted and oysters $\geq$ MLS are retained. Owing to constraints of time and access the focus of this study is the sail fishery and Harbour section.

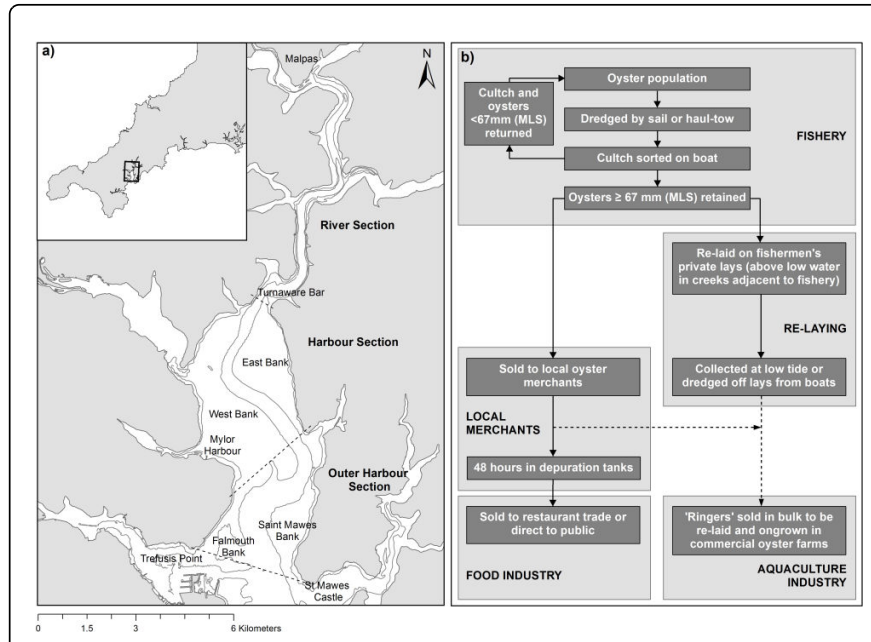

Figure 1: Overview of the Fal wild native oyster fishery. Map a) shows the extent of fishery, constrained by mean low water mark, from southerly limit (line from Trefusis Point to St Mawes Castle) and northerly limit (Malpas), $0 \mathrm{~m}$ and $5 \mathrm{~m}$ contour lines are drawn. Schematic b) shows movement of oysters from fishery to market. Note it is not clear what proportion of ringers (oyster $\geq$ MLS but too small for food industry) are sold directly to aquaculture industry by fishermen or via local merchants or both (indicated with dashed line).

\section{Historical data on fishing fleet}

A historic record of the number of sail and haul-tow boats working the Fal fishery was identified, covering the period 1910 to 1973 [35]. Available data on the estimated landings and number of dredge licences was obtained from the Port of Truro, this covered the period from 1995 to 2013. Estimated landings are the sum of total weights purchased in the season by individual merchants known to purchase Fal oysters from fishermen. Oysters purchased by merchants may include both direct landings from the fishery and oysters gathered from re-laid stocks.

\section{Dredging survey}

'Dredge gear' refers to the gear towed across seabed, whilst dredge refers to the activity of deploying, towing and hauling the dredge gear. The two dredge gears used on board the sailing boat from which data were gathered were typical of those used in the fishery. Constructed from stainless steel with the widths of the front edge of $75 \mathrm{~cm}$ and 70 $\mathrm{cm}, 60 \mathrm{~mm}$ belly rings (to resist abrasion and provide free passage to material $<60 \mathrm{~mm}$ ) and a nylon mesh bag. Data were collected by an observer on board one sailing boat on 6 days in February and March 2014. Upon hauling, fishers sort the dredge contents (cultch) and select oysters to retain, depositing the rest of the dredge contents overboard. 
Page 3 of 7

For each dredge the number of oysters retained was recorded. For each retained oyster the wet weight $( \pm 5 \mathrm{~g}$, Pesola spring balance) and maximum diameter of each oyster $( \pm 0.5 \mathrm{~mm}$, Vernier callipers $)$ was determined. Prior to weighing, any material, organic or otherwise, attached to, or to which the oyster was attached, was removed. For a sub-sample of 15 dredges all the oyster in each dredge were examined; counting, weighing and measuring the oysters (using the above procedure) returned, in addition to those retained by the fisherman. The start time (dredge gear deployment) and finish time (hauling the dredge gear) were noted for each dredge. Catch per Unit Effort (CPUE) is the number of oysters caught per $\mathrm{m}^{2}$ of seabed dredged. Area of seabed covered by each dredge was determined by multiplying the mean dredge gear width $(0.725 \mathrm{~m})$ by the distance covered by the dredge between the start and finish time of each tow.

\section{Vessel monitoring}

GPS data loggers (i-gotu gt-100 and i-gotu gt-600 GPS) combined with external battery packs were placed on two sailing boats based at Mylor Harbour from February 19th 2014 to the end of the season March 31st 2014. Locations of individual dredges and vessel tracks were all obtained using GPS logger data. Positions of vessels were logged every 30 seconds during the hours of fishery operation. Spatial analysis was conducted using ArcGIS 10.1 [36] in conjunction with Geospatial Modelling Environment [37]. Number of sailing vessels was surveyed from Weir Point, Fal estuary (N50 11' 25', W005 3' 23”), on 24 days between February 5th 2014 and February 31st 2014 inclusive. Counts took place between $\sim 09: 30$ and 14:30 each day. Mean wind speed between 09:00 and 15:00 was calculated from weather station observations at Culdrose, Cornwall (UK Met Office station; $\mathrm{N} \mathrm{50^{ \circ }} 5^{\prime}$ 2.4", W005 $15^{\prime} 32.4$ ") [38]. The total number of sailing boats was modelled using a Generalised Additive Model (GAM) using a smoothing spline fit, with mean wind speed as the explanatory variable and a Poisson error structure. This allowed an estimate of the number of fishable days per season based on suitable weather conditions.

\section{Effort comparison}

Data from the dredging survey and vessel monitoring activities were used to estimate effort expended per day $\left(\mathrm{m}^{2}\right.$ fisher ${ }^{-1}$ day $\left.^{-1}\right)$ and per season by an individual fisher. No comparable figure for a motorised vessel was available in the literature. Thus an equivalent estimate of effort was developed for a motorised vessel operating dredges in this fishery. For the purpose of this estimation, dredge width was the maximum dictated by existing byelaw in the Thames estuary, which is a motorised fishery [39]. The dredge speed used was the averaging towing speed used in dredge surveys in the Fal undertaken by Cefas [25], as this is the only known example of motorised dredging in the Fal. The percentage of time spent dredging during fishery hours using a motorised vessel (95\%) was set based on discussion with local fishermen in relation to observations during dredging survey. Note journeying to and from oyster beds is excluded from the fishery hours. The percentage of fishable days was determined from the number of days in the 2012/13 and 2013/14 where the observed mean wind speed was $<30 \mathrm{mph}$, note the fishery is more sheltered than the wind observation site (Culdrose, see above).

\section{Results}

\section{Fleet statistics and landings}

The total number of boats and the ratio of sail to haul-tow boats varied greatly between 1910 and 1972 (Figure 2). At its height, in 1922, the fishery supported 189 boats, 144 haul-tow and 45 sail. Unfortunately, a more recent continuous record is not available; however, in 2009 there were approximately 12 sailing boats in the fleet [18]. In the 2013/14 season there were 16 registered sailing boats, and 14 registered haul-tow boats. Of these only 6 sailing boats and 5 haultow boats fished most suitable days, with the rest being used occasionally or rarely (P. Ferris, pers. comm.). Landings and licences peaked in 1996 at 117 tonnes and 87 licences. The subsequent trend is a decline to 47 tonnes and 55 licences in 2012. Although the lowest landings and number of licences was recorded in 2005, with 24 tonnes and 41 licences (Figure 3).

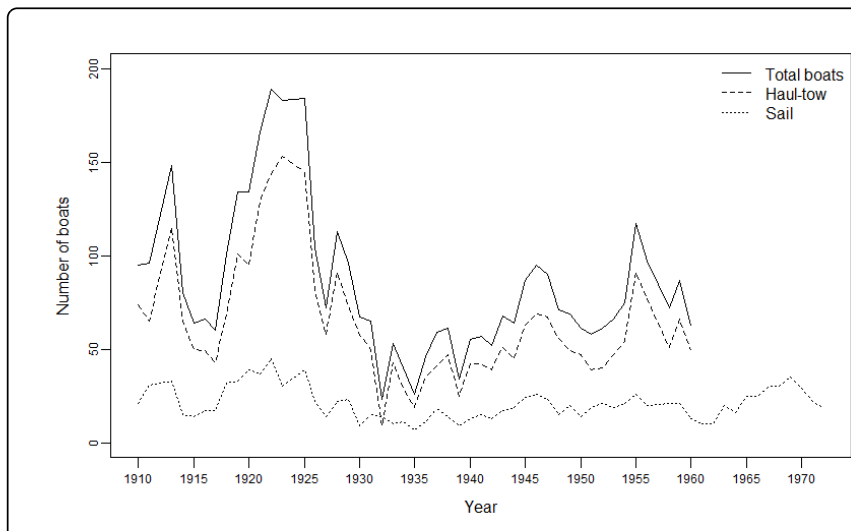

Figure 2: Historic numbers of boats operating in the Fal oyster fishery. With total (solid line), sail (short dashes) and haul-tow (long dashes) boat numbers between 1910 and 1972. Between 1910 and 1960 only years where both number of sail and haul-tow were available are plotted. From 1961 to 1972 only the number of sail boats was available. Note year refers the year in which the season starts, thus 1910 is the 1910/11 season. Data: Davies, 1989.

\section{Dredging survey}

Data were collected from 238 separate dredges. The median distance dredged was $98 \mathrm{~m}(\mathrm{IQR}=56.7-149.8, \mathrm{n}=238)$, representing a median area per dredge of $71 \mathrm{~m}^{2}(\mathrm{IQR}=41.1-108.6, \mathrm{n}=238)$. The median number of oysters retained was 2 oysters dredge ${ }^{-1}(\mathrm{IQR}=1-4, \mathrm{n}=238)$, which equates to a median CPUE of 0.03 oysters per $\mathrm{m}^{2}$ dredged (IQR $=0.012-0.061, \mathrm{n}=238$; Figure $4 \mathrm{a})$. The mean dredge duration was 5.7 minutes ( $\mathrm{sd}=2.3, \mathrm{n}=238$ ). The median wet weight of retained oysters was $80 \mathrm{~g}(\mathrm{IQR}=70-105, \mathrm{n}=652$; Figure $4 \mathrm{~b})$, with a median maximum diameter of $78 \mathrm{~mm}$ (IQR=74-86, $\mathrm{n}=652$; Figure $4 \mathrm{c})$. CPUE was shown to vary spatially. 
Page 4 of 7

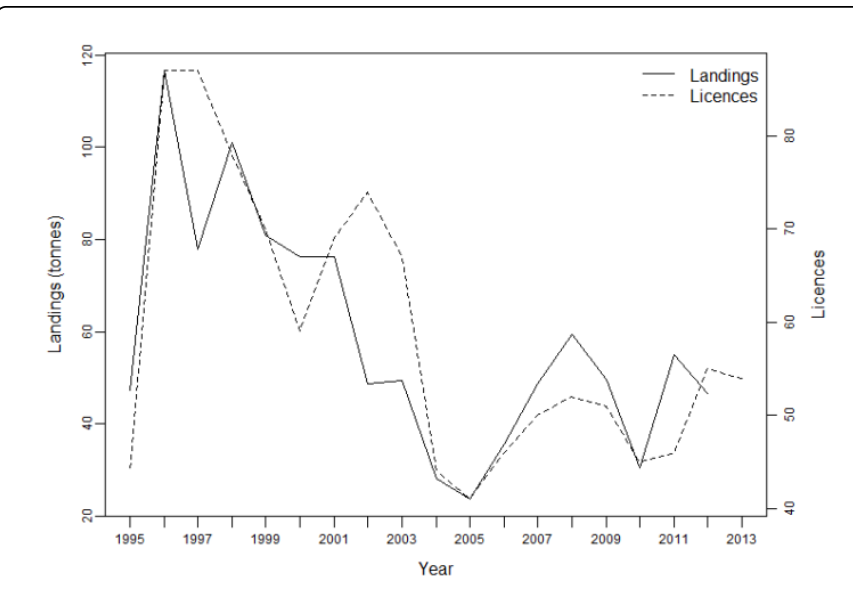

Figure 3: Recent trends in landings and licences, in the Fal oyster fishery. Between 1995 and 2013, note year refers the year in which the season starts, thus 1995 is the 1995/96 season. Landings are indicated with and solid line and licences with a dashed line. Data: P. Ferris, Port of Truro.
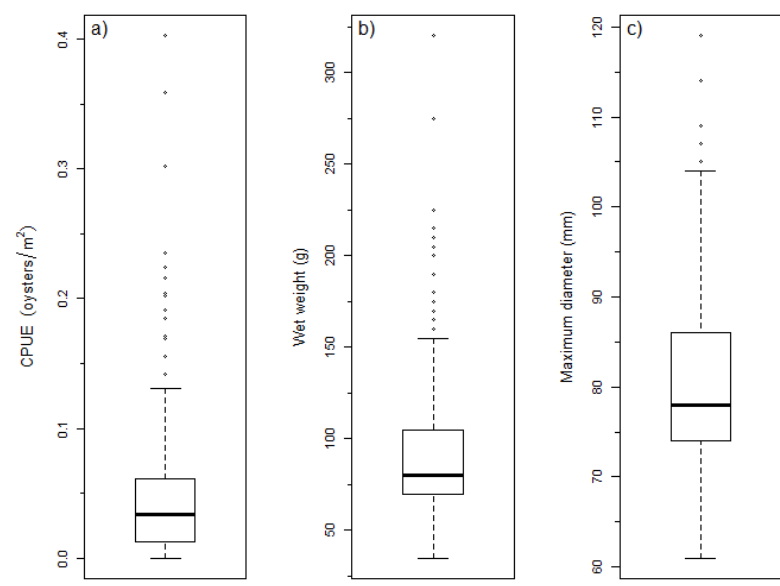

Figure 4: Box-whisker plots of metrics from dredges from observer on board a sailing vessel in the Fal oyster fishery, Cornwall. Where a) shows the Catch per Unit Effort $\left(\right.$ oyster $\left.\left.\mathrm{m}^{-2}\right)(\mathrm{n}=238), \mathrm{b}\right)$ shows the wet weight $(\mathrm{g})(\mathrm{n}=652)$ and $\mathrm{c})$ shows the maximum diameter $(\mathrm{mm})(\mathrm{n}=652)$. Median is indicated by a thick back line. The box represents the interquartile range (IQR) bounded by the $25^{\text {th }}(\mathrm{Q} 1)$ and $75^{\text {th }}(\mathrm{Q} 3)$ percentiles. The lower whisker is drawn at the larger of: the minimum value $\mathrm{x}$ and $\mathrm{Q} 1-1.5^{\star} \mathrm{IQR}$. The upper whisker is drawn at the smaller of: the maximum value of $x$ and $Q 3+1.5^{\star} \mathrm{IQR}$. Outliers are indicated by open circles.

For a sub-sample of 15 dredges, all oysters in the haul were weighed and measured. The median number of oysters $\geq$ MLS was 3 oysters per dredge (IQR $=1.5-3.5, \mathrm{n}=15$ ), with a median CPUE of 0.04 oysters $\mathrm{m}^{-2}$ dredged (IQR=0.019-0.097, $\mathrm{n}=15$ ). The median wet weight of oysters $\geq$ MLS was $63 \mathrm{~g}(\mathrm{IQR}=46.3-90.0, \mathrm{n}=54)$, with a median maximum diameter of $74 \mathrm{~mm}$ (IQR=70.3-80.0, $\mathrm{n}=54)$.

\section{Vessel monitoring}

Towards the latter end of the season, including the period GPS loggers were installed, sail boat dredging effort was concentrated on the East bank (Figure 5a). Using data collected from sailing vessels the dredging effort $\left(\mathrm{km}^{2}\right.$ fisher ${ }^{-1}$ day $\left.^{-1}\right)$ exerted by one fisher per day was estimated (Table 1). This was extrapolated to estimate effort expended in a season. This was achieved by estimating the percentage of fishable days, using a modelled relationship between mean wind speed and number of sailing vessel fishing from observed wind speeds in the last two seasons. Visual census of the fleet highlighted dependency on suitable wind conditions, with only $62.1 \%$ of days fishable by at least one boat in the previous two seasons (Table 1). For comparison the effort expended by a fisher in a motorised vessel is estimated (Table 1). Fishing is not continuous, dredging ceases whilst sailing back up tide and wind (Figure $5 \mathrm{~b}$ ), with dredges only deployed $87 \%$ of the time, excluding sailing to and from harbour (Table 1).

\begin{tabular}{|c|c|c|c|}
\hline \multirow{2}{*}{ Metric } & \multicolumn{2}{|c|}{ Vessel Type: } & \multirow[t]{2}{*}{ Unit } \\
\hline & Sailing & Motorised & \\
\hline Width of dredge & 0.7 & $2 \S$ & $\mathrm{m}$ \\
\hline Number of dredges & 2 & 2 & \\
\hline Speed & $1.3^{*}$ & $3^{* *}$ & $\mathrm{~km} \mathrm{~h}^{-1}$ \\
\hline Hours in fishery day & 6 & 6 & hours \\
\hline $\begin{array}{l}\text { Percentage of time spent } \\
\text { dredging }\end{array}$ & $86.8 \dagger$ & $95+t$ & $\%$ \\
\hline Effort per day & 9,479 & 68,400 & $\mathrm{~m}^{2}$ fisher $^{-1}$ day $^{-1}$ \\
\hline Number of days in season & 182 & 182 & days \\
\hline Percentage of fishable days & $62.1 \ddagger$ & $84.6 \ddagger \ddagger$ & $\%$ \\
\hline Number of fishable days & 113 & 154 & days \\
\hline Total effort per season & 1.1 & 10.5 & $\begin{array}{ll}\mathrm{km}^{2} & \text { fisher }^{-1} \\
\text { season-1 }^{-1} & \end{array}$ \\
\hline
\end{tabular}

* Mean dredging speed recorded by observer on two full days of fishing $(19 / 02 / 14$ and $21 / 03 / 14)$

$\dagger$ Percentage of time one or more dredges were deployed during one full day of fishing $(19 / 02 / 14)$

¥ Percentage of days, in the last 2 seasons, where GAM (Figure 1, Supporting Information) predicts at least one sailing vessel in operation, from observed wind speeds

$\S$ As per maximum aggregate blade width $(4 \mathrm{~m})$ dictated by byelaw in Thames estuary oyster fishery, represented here as two $2 \mathrm{~m}$ dredges

** Average speed of motorised vessel $(7.9 \mathrm{~m}, 60 \mathrm{~kW})$ used by Cefas during oyster surveys for towing dredges in the Fal oyster fishery.

†† allowing $5 \%$ of time for hauling, emptying and re-deploying dredges

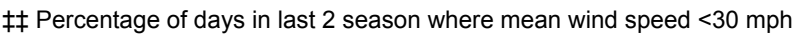

Table 1: Comparison of effort between sail and motorised dredging. Based on GPS and observer data from sailing vessels and stated assumptions for the operation of motorised vessels. 


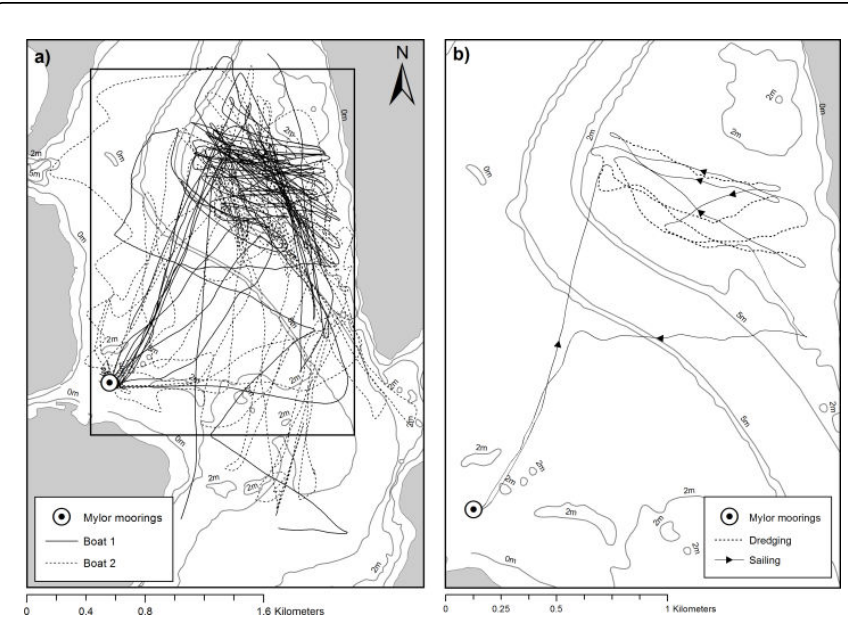

Figure 5: GPS tracks of a) Two sailing boats in fleet and b) a typical dredging trip. Where a) shows 13 oyster dredging trips between $19 / 20 / 2014$ and 31/03/2014 inclusive, undertaken by boat 1 (7 trips) and boat 2 (6 trips) and b) a single trip on 19/02/2014 differentiating between periods of travel 'Sailing' and oyster fishing 'Dredging. For b) periods of oyster fishing 'Dredging' determined by board observer recording times when dredges were in operation. GPS data loggers recorded position every 30 seconds. Tracks smoothed using Polynomial Approximation with Exponential Kernel (PAEK) smoothing with $100 \mathrm{~m}$ tolerance.

\section{Effort comparison}

The estimated effort expended using a sailing vessel was $9,479 \mathrm{~m}^{2}$ fisher ${ }^{-1}$ day $^{-1}$ and $1.1 \mathrm{~km}^{2}$ fisher ${ }^{-1}$ season $^{-1}$, compared with $68,400 \mathrm{~m}^{2}$ fisher ${ }^{-1}$ day $^{-1}$ and $10.5 \mathrm{~km}^{2}$ fisher ${ }^{-1}$ season $^{-1}$ for a motorised vessel, based on the predicted number of fishable days for the respective vessels (Table 1).

\section{Discussion}

\section{Long-term trends}

Historically levels of exploitation were much higher, with the fishery supporting 189 boats at its peak in 1922. Davies (35) attributes the expansion and contraction of the fleet to changes in stock levels, with variation in the ratio of sail to haul-tow boats likely reflecting changes in oyster abundance in the Harbour and River sections of the fishery. The onset of Bonamia in 1982 reduced landings, from 120-250 tonnes year $^{-1}$ in the years immediately preceding the first record, to an average of 20 tonnes year ${ }^{-1}$ between 1983 and 1992 [24]. Surveys in 1986 and 1988 found stocks were very low [25], though historical data suggests there was a recovery of stocks and consequently the fishery in the 1990s. Following a low-level mortality event in 2010, testing of $O$. edulis from the Fal confirmed the presence of $B$. osteae and $B$ exitiosa, although subsequent testing for $B$. exitiosa has been negative suggesting it has not become established [40].

Unfortunately, reliable and comprehensive historical data on landings are unavailable. However, Davies [35] reports the largest quantity of oysters from a single season to be approximately 3.5 million oysters in 1953/54 season. The basis of this estimate is not clear, although it is known at this time oysters were sold by number rather than weight. Assuming that the wet weight of individual oysters landed was $74 \mathrm{~g}$ (mean weight of oyster $\geq$ MLS from 15 dredge sub-sample), this equates to an estimated landing of 258 tonnes in the 1953/54. This estimate would represent a 5.5 fold decrease in landings from 1953/54 to $2012 / 13$. This, in conjunction with greater levels of effort, strongly suggests historic landings exceed current catches. Overall, annual licences granted, whilst indicative, cannot be used as a direct proxy for effort. Some dredge licences are bought and used infrequently (P. Ferris, pers. comm.). Current landings figures are also not necessarily an accurate record of the total weight of oysters landed from the fishery in a season. The landings figures presented in this study were obtained from the previous management authority (Port of Truro), who produced the data annually by contacting known merchants and enquiring as to the total weight purchased each season. The landing figures do not differentiate between oysters dredged directly from the fishery and those gathered having previously been re-laid. Furthermore, fishermen may use routes to markets that exclude the merchants surveyed each year. However, data is sufficient to conclude there has been a decline in both the landings and licences. Landings in the $2012 / 13$ season of 46.6 tonnes are $40 \%$ lower than the recent peak of 116.7 tonnes in $1996 / 97$ and $82 \%$ lower than the historic peak, estimated to be 258 tonnes in 1953/54. It is not clear whether the trend in recent years is a decline in landings due to reduced effort, or a decline in landings due to declining stocks.

\section{Inefficiency of traditional dredging methods}

A unique feature of the Fal oyster fishery is the traditional methods employed. The mean dredge duration of 5.7 minutes $(\mathrm{sd}=2.34, \mathrm{n}=238)$ observed in this study, is approximately the same as the 6 minute duration reported almost eight decades ago [41]. This likely indicates fishing practices have remained unchanged, in sharp contrast to the advances in gear and technology deployed in other fisheries in the last century. There are a number of factors pertaining to the traditional methods that limit the comparative efficiency of the fishery. Dredge gear size is physically limited to what can be hauled by hand. The reliance on suitable weather conditions means it is estimated only $62.1 \%$ of days (113 of 182 days, per season) were fishable in the 2012/13 and 2013/14 two seasons. Sub-optimal wind conditions typical result in fewer boats fishing and sub-optimal dredge speeds, further reducing efficiency. These factors limit the effort in a fishery that exhibits low CPUE.

Consideration should be given to the fact that the fisherman observed in this study has not been dredging for as many years as some others operating boats in the fleet. Fishermen operating within the fishery for longer may benefit from greater CPUE. Experience would improve boat handling to optimise dredge speed, better target productive areas and minimise time spent re-positioning the boat. The efficiency of the dredge gear used in the fishery is not known and likely varies with factors identified by Gosling [42] including; the nature of the seabed, operating conditions and the skill of the fisherman. No applicable estimate of hand dredge efficiency could be found in the literature. A good estimate could be obtained by dredging an area such as Turnaware Bar having first determined actual density by a quadrat based survey. This would allow a better understanding of the dynamics of the fishery. An estimate of dredge efficiency would allow catch-perdredge figures, from this study and annual surveys [25,29], to be converted to actual abundance in order to estimate the total population. 


\section{Could inefficiency account for the longevity of the fishery?}

Given the highly variable and sporadic nature of recruitment, severe population reduction caused by Bonamia and the fluctuation in fleet size it is difficult to determine whether levels of exploitation are, or have been, sustainable. Some authors suggest there have been periods of over-fishing. Orton [41] concluded that 'the population of oysters... continues to decrease as a result of more oysters being taken from the beds than are being replaced by natural means. Cove [43] reported that there were episodes of over-fishing in previous decades. However, despite potential episodes of over-fishing and the severe population reduction caused by Bonamia the fishery has avoided collapse. It is worth noting both remaining wild native oyster fisheries in England, Thames estuary and Solent, which deploy modern methods, effected temporary closures in the 2013/14 season to protect severely depleted stocks (Kent and Essex IFCA, 2013; Sussex IFCA, 2013) [39,44]. The Thames estuary oyster fishery closure was subsequently extended to cover the 2015/16 to 2017/18 seasons [45], whilst the Solent fishery has extended closures for the 2014/15, 2015/16 and 2016/17 seasons [46-48]. The longevity and survival of the Fal fishery is therefore notable.

Motorised vessels would dramatically increase the total units of effort per day and increase the number of fishable days in the season, resulting in a greater than 9 fold increase in the level of effort per season (Table 1). Reviewing declines in Crassostrea virginica fisheries of the USA, Mackenzie [49] highlights the increases in productivity brought by the motorization of fleets, allowing fishing on days when wind conditions prevented sailing. Further, mechanical power would allow heavier dredge gear, which would likely increase CPUE. This means that the actual difference in effort between sail and motor is likely greater than the conservative estimate made here. Heavy mechanical gears would also likely damage benthic habitat and structure with potential effects on recruitment. This has been reported in $C$. virginca fisheries in the USA, examples include studies in the Chesapeake Bay fishery [50] and Neuse River fishery [6]. The unique nature of the fishery means comparisons with other cannot be readily drawn, thus the ecological and physical impact of gears currently used is not known. Nevertheless, it is worth noting that Lenihan and Peterson [51] report that a $1 \mathrm{~m}$ wide $25 \mathrm{~kg}$ dredge deployed from a powered vessel reduced the height of experimentally restored $C$. virginica reefs by $34 \%$, in the Neuse River, North Carolina.

The authors are not aware of any other examples where the prohibition of powered vessels is currently used as a management measure in an oyster fishery. This management measure was formerly applied in the Chesapeake Bay oyster fishery, USA. Rothschild, et al. [50] report that the restriction of dredging to sail-powered vessels to constrain effort was of limited effectiveness; identifying the sheer number of vessels, $>1000$ by 1890 [52], being responsible for the unsustainable level of effort in spite of the restriction. The review identified intense fishing pressure leading to mechanical destruction of habitat-the degradation of oyster bar structure, shallowing of bar profiles, removal of settlement substrate and resulting siltation-as one of the primary causes of decline but state this pre-dated industrialisation [50]. A similar explanation may apply to the Fal oyster fishery where significantly higher levels of effort in the early part of the 20th century ultimately led to declines in catch and effort. In the present day Fal estuary fishery restriction to non-powered caps efficiency and renders profitability marginal.

There is currently no limit imposed by the management authority on landings or licenses. It is the marginal profitability of traditional fishing which limits the size of the fleet. If over-exploitation induced stock declines have occurred it has likely resulted in decreased effort before the point of fishery collapse could be reached. There is increasing recognition that the industrialisation of fishing and resulting increase in fishing power has dramatically reduced stocks, altered marine ecosystems and led to fishery collapses throughout the North Atlantic Ocean $[26,27]$. The key to the longevity of this fishery may therefore be the inherent inefficiency of the capture method, which ensures a low CPUE and renders over-exploitation to collapse economically unfeasible.

\section{Conclusion}

This study aimed to gain insights into sustainability of the Fal oyster fishery. The timing is pertinent as the long standing regulating order has expired. Management is now in the remit of the Cornwall Inshore Fisheries and Conservation Authority (CIFCA) and regulated by the 2016 order. With increasing interest in the restoration of oyster beds in the UK [15] and globally, the Fal oyster fishery may offer a unique 'model' approach to the management of wild oyster fisheries. Whilst causality is difficult to establish in a data deficient fishery and is beyond of the scope of the data presented here, the fishery's longevity is noteworthy and could be considered an indicator of sustainability. Although a more accurate description could be a state of flux between over-exploitation and reduced effort allowing recovery. Given the stock is demonstrably vulnerable to additional pressures as demonstrated by the impacts of Bonamia in the 1980s, management measures should aim to increase the resilience of the fishery as well as recruitment to increase productivity. The crucial feature of the existing regulation of this fishery, and hence its long term survival, seems to be the inherent inefficiency of the traditional methods of dredging employed, which it is conservatively estimated results in at least 9 times less effort per season than if the fleet were motorised.

\section{Acknowledgements}

The authors would like to thank the following without whom the above would not have been possible. A. Spargo, who initiated the project, provided access to his boat, offered candid insights into the fishery and introduced an amateur to the art of sailing. R. Chapman for agreeing to install a GPS logger on his boat. C. Ranger for sharing data and providing insight from a merchant's perspective. Port of Truro, in particular P. Ferris for sharing knowledge of the fishery and providing data. K. Vaasteen at Cefas for granting access to the annual survey of the oyster population. Officers of the Cornwall Inshore Fisheries and Conservation Authority who provided guidance. J. Beswick who assisted with data collection. The manuscript was significantly improved by the comments of anonymous reviewers.

\section{References}

1. Jackson JB, Kirby MX, Berger WH, Bjorndal KA, Botsford LW, et al. (2001) Historical overfishing and the recent collapse of coastal ecosystems. Science 293: 629-637. Srinivasan UT, Cheung WW, Watson R, Sumaila UR (2010) Food security implications of global marine catch losses due to overfishing. Journal of Bioeconomics 12: 183-200.

2. Pauly D, Christensen V, Guénette S, Pitcher TJ, Sumaila UR, et al. (2002) Towards sustainability in world fisheries. Nature 418: 689-695.

3. Worm B, Hilborn R, Baum JK, Branch TA, Collie JS, et al. (2009) Rebuilding global fisheries. Science 325: 578-585.

4. Nielsen EE, Kenchington E (2001) A new approach to prioritizing marine fish and shellfish populations for conservation. Fish Fish 2: 328-343. 
5. Lenihan HS, Peterson CH (1998) How habitat degradation through fishery disturbance enhances impacts of hypoxia on oyster reefs. Ecol Appl 8: 128-140.

6. $\quad$ Coen LD, Brumbaugh RD, Bushek D, Grizzle R, Luckenbach MW, et al. (2007) Ecosystem services related to oyster restoration. Mar Ecol Prog Ser 341: 303-307.

7. FAO (2015) FIGIS (Fisheries Global Information System). Fisheries Commodities and Trade 1976-2012, Rome.

8. FAO (2015) FIGIS (Fisheries Global Information System). Global capture production 1950-2013, Rome.

9. Beck MW, Brumbaugh RD, Airoldi L, Carranza A, Coen LD, et al. (2011) Oyster reefs at risk and recommendations for conservation, restoration, and management. Bioscience 61: 107-116.

10. Lallias D, Boudry P, Lapegue S, King JW, Beaumont AR (2010) Strategies for the retention of high genetic variability in European flat oyster (Ostrea edulis) restoration programmes. Conserv Genet 11: 1899.

11. OSPAR Commission (2008) OSPAR List of Threatened and/or Declining Species and Habitats.

12. Kennedy R, Roberts D (1999) A survey of the current status of the flat oyster Ostrea edulis in Strangford Lough, Northern Ireland, with a view to the restoration of its oyster beds. Proceedings of the Royal Irish Academy B Biology \& Environment Proceedings of the Royal Irish Academy 99: 79-88.

13. Smyth D, Roberts D, Browne L (2009) Impacts of unregulated harvesting on a recovering stock of native oysters (Ostrea edulis). Mar Pollut Bull 58: 916-922.

14. Laing I, Walker P, Areal F (2006) Return of the native is European oyster (Ostrea edulis) stock restoration in the UK feasible. Aquat Living Resour 19: 283-287.

15. Laing I, Walker P, Areal F (2005) A feasibility study of native oyster (Ostrea edulis) stock regeneration in the United Kingdom. Centre for Environment, Fisheries \& Aquaculture Science.

16. MMO (2015) Monthly UK Sea Fisheries Statistics-Reported Landings. Marine Management Organisation.

17. Royal Haskoning (2009) Falmouth Cruise Project Environmental Statement. Marine Ecological Survey.

18. Council of the European Commission (1992) Council Directive 92/43/EEC of 21 May 1992 on the conservation of natural habitats and of wild flora and fauna. Official Journal of the European Community Series L 206: 7-49.

19. Hudson E, Hill B (1991) Impact and spread of bonamiasis in the UK. Aquaculture 93: 279-85.

20. Laing I, Spencer BE (2006) Bivalve cultivation: criteria for selecting a site. Centre for Environment Fisheries and Aquaculture Science pp: 1467-5609.

21. Héral M, Deslous-Paoli J (1991) Oyster culture in European countries. Estuarine and Marine bivalve mollusc culture. Boca Raton, Florida pp: 154-190.

22. DEFRA (2006) Council Regulation (EC) No 510/2006 on protected geographical indications and protected designations of origin "Fal Oyster". Department for Environment, Food and Rural Affairs.

23. Laing I, Dunn P, Peeler E, Feist S, Longshaw M (2014) Epidemiology of Bonamia in the UK 1982 to 2012. Dis Aquat Organ 110: 101-111.

24. Cefas (2012) Truro Oyster Fishery Annual Survey 2012 Fal Estaury, Cornwall. Centre for Environment, Fisheries and Aquaculture Science.

25. Thurstan RH, Roberts CM (2010) Ecological meltdown in the Firth of Clyde, Scotland: two centuries of change in a coastal marine ecosystem. Plos One 5: e11767.

26. Thurstan RH, Brockington S, Roberts CM (2010) The effects of 118 years of industrial fishing on UK bottom trawl fisheries. Nat Commun 1: 15.
27. HM Government (1975) Truro Port Fishery (Variation) Order.

28. Cefas (2013) Truro Oyster Fishery Annual Survey 2013 Fal Estuary, Conrwall. Centre for Environment, Fisheries and Aquaculture Science.

29. HM Government (1936) Truro Port Fishery Order.

30. Port of Truro (2013) Ports of Truro, Penryn, Prince of Wales Pier, Portscatho and Newquay Harbours Fees and Charges.

31. CIFCA (2015) Fal Shellfish Fishery Emergency Byelaw. Impact Assessment: Cornwall Inshore Fisheries and Conservation Authority.

32. CIFCA (2009) Fal Shellfish Fishery Emergency Byelaw. Cornwall Inshore Fisheries and Conservation Authority.

33. HM Government (2016) The Fal Fishery Order 2016.

34. Davies A (2002) The History of Falmouth Working Boats. Falmouth, UK.

35. ESRI (2013) Relands, CA. Environmental Systems Research.

36. Beyer HL (2010) Geospatial modelling environment.

37. Met Office (2014) Culdrose Observations.

38. KEIFCA (2013) Shellfish Beds Byelaw: Temporary prohibition on taking native oysters. Kent \& Essex Inshore Fishery and Conservation Authority.

39. Longshaw M, Stone DM, Wood G, Green MJ, White P (2013) Detection of Bonamia exitiosa (Haplosporidia) in European flat oysters Ostrea edulis cultivated in mainland Britain. Diseases of Aquatic Organisms 106: 173-179.

40. Orton J (1927) Observations on the Fal estuary oyster beds during 1926, including a study in over-fishing. Journal of the Marine Biological Association of the United Kingdom 14: 923-934.

41. Gosling E (2008) Bivalve molluscs: biology, ecology and culture. John Wiley \& Sons.

42. Cove J (1973) Hunters, trappers, and gatherers of the sea: a comparative study of fishing strategies. Journal of the Fisheries Board of Canada 30: 249-259.

43. SIFCA (2013) Sussex IFCA introduce adaptive management measures to protect oyster stock. Emergency Temporary Closure of Shellfish Fisheries Byelaw. Sussex Inshore Fisheries and Conservation Authority.

44. KEIFCA (2015) Byelaw Area A. Kent \& Essex Inshore Fishery and Conservation Authority.

45. SIFCA (2014) Temporary closures of shellfish bed byelaw. Sussex Inshore Fisheries and Conservation Authority.

46. SIFCA (2015) Temporary closures of shellfish bed byelaw. Sussex Inshore Fisheries and Conservation Authority.

47. SIFCA (2016) SIFCA Solent oyster temporary closure notice: Sussex Inshore Fisheries and Conservation Authority.

48. Mackenzie CL (2007) Causes underlying the historical decline in eastern oyster (Crassostrea virginica Gmelin, 1791) landings. J Shellfish Res 26: 927-938.

49. Rothschild B, Ault J, Goulletquer P, Heral M (1994) Decline of the Chesapeake Bay oyster population: a century of habitat destruction and overfishing. Mar Ecol Prog Ser 111: 29-39.

50. Lenihan HS, Peterson CH (2004) Conserving oyster reef habitat by switching from dredging and tonging to diver-harvesting. Fish B Noaa 102: 298-305.

51. Stevenson CH (1894) The oyster industry of Maryland. Causes underlying the historical decline in eastern oyster landings Journal of Shellfish Research pp: 927-938.

52. U.S. Commission of Fisheries (1901) Decline of the Chesapeake Bay oyster population: a century of habitat destruction and overfishing. Marine Ecology Progress Series pp: 29-39. 